\title{
VARIABILITY OF SEED-BORNE Colletotrichum STRAINS IN COTTON BASED ON ITS1 AND ITS2 RIBOSSOMAL GENES ANALYSIS
}

\author{
VARIABILIDADE DE ESTIRPES DE Colletotrichum PROVENIENTES DE \\ SEMENTES DE ALGODÃO COM BASE NA ANÁLISE DOS GENES RIBOSSOMAIS \\ ITS1 E ITS2
}

\section{Enia Mara de CARVALHO ${ }^{1}$; Antônia dos Reis FIGUEIRA ${ }^{2}$; José da Cruz MACHADO² Dejânia Vieira de ARAÚJO' ${ }^{3}$; Cibele Ferreira MACHADO ${ }^{4}$}

1. Universitary Barra Mansa / Center of Barra Mansa (UBM, Centro, Barra Mansa, RJ, Brazil; 2. Plant Pathology Department, Federal University of Lavras - UFLA, Lavras, MG, Brazil; 3. Crop Science Department, Mato Grosso State University - UNEMAT, Tangará da Serra, MT, Brazil; 4. Biotechnology Laboratory, Dow AgroSciences, Jardinópolis, SP, Brazil

\begin{abstract}
The use of DNA sequences analysis has been an important mean to distinguish and to identify populations of organisms at different levels. By molecular markers several complex organisms have been successful detected in plants for distinct aims. Ribosomal DNA (rDNA) has been used to evaluate genetic variability, microorganism phylogeny and to develop specific primers for detection of plant pathogens in plant tissues. In this study, the objective was to characterize isolates of Colletotrichum gossypii var. cephalosporioides and Colletotrichum gossypii, collected in different regions of Brazil, by analyzing the nucleotide sequence of rDNA regions. ITS1, ITS2, and the intervening 5.8S gene were amplified by PCR and their sequences compared to each other and to those from other species registered in the GenBank. The rDNA of isolates associated with Gossypium spp. showed sequence identities ranging from 96 to $100 \%$ in the ITS1 region, 98 to $100 \%$ in the $5.8 \mathrm{~S}$ gene, and 97 to $100 \%$ in the ITS2 region. The sequences were submitted to UPGMA analysis, and according to the phylogenetic trees, the $C$. gossypii var. cephalosporioides and $C$. gossypii species clustered together along with isolates of Glomerella cingulata from mango and papaya, and thus no distinction could be made between isolates of those organisms.
\end{abstract}

KEYWORDS: Colletotrichum gossypii. Colletotrichum gossypii var. cephalosporioides. rDNA. Phylogeny. Gossypium spp.

\section{INTRODUCTION}

Anthracnose and ramulosis, caused by the seed-transmitted fungi Colletotrichum gossypii South. and Colletotrichum gossypii var. cephalosporioides A. S. Costa, respectively, are widespread diseases of cotton with high potential to severely reduce yields (LIMA et al., 1985; TANAKA, 1995). Moreover, the amount of inoculum of both pathogens on cotton seeds influences the disease progress at variable levels of incidence and inoculum severity (ARAÚJO et al., 2006).

The species C. gossypii, described by Southworth in 1890 (VIÉGAS, 1946), was subsequently reported by Arx (1957) as belonging to the C. gloeosporioides group, with Glomerella cingulata as the teleomorph. In cotton plants, the cephalosporioides variety, the causal agent of ramulosis, reported by Costa and Fraga (1937) and described by Costa in 1946 (VIÉGAS, 1946), was first identified in the State of São Paulo, associated with the witch's broom symptoms, which were not observed in the strains that cause anthracnose.

Sutton (1992) considered Colletotrichum gossypii var. cephalosporioides a distinct group.
According to the cultural, pathogenic and serological characteristics, Ottonello (1992) suggested that such group could be divided in two forma specialis subgroups of $C$. gloeosporioides $\mathrm{f}$. sp. gossypii. The first subgroup, represented by race 1 , should be composed of strains not associated with dieback symptoms and, therefore, the cause of anthracnose disease. The second subgroup, represented by race 2 of $C$. gloeosporioides $\mathrm{f}$. sp. gossypii, is composed of those strains inducing witch's broom symptoms, the causal agent of ramulosis disease.

Great variation in aggressiveness of Colletotrichum strains has been observed by several authors (DUDIENAS, 1990; TANAKA, 1990; IAMAMOTO, 2002; SILVA-MANN, 2002), suggesting the presence of physiological races, and according to Chitarra (1996), the strains that cause ramulosis are not clearly distinguishable from the ones that cause anthracnose. The studies of the relationship between the pathogen and the host are usually conducted with strains isolated directly from plants exhibiting the typical disease symptoms to ensure the capability of strains to induce the abovementioned symptoms. 
The use of DNA sequences seems to be a reliable tool in defining genetically related groups of microorganisms in comparison with studies including disease symptoms (VIEIRA, 2002; VIEIRA and MACHADO, 2002). Most of the studies on genetic variability of strains from the Colletotrichum complex in cotton are based on polymorphism among randomly amplified DNA fragments (CHITARRA, 1996; VIEIRA, 1996; MEHTA et al., 2001; SILVA-MANN et al., 2002, 2005) and isozyme patterns (VIEIRA, 1996; CARVALHO et al., 1997). From the results of those studies, it is concluded that the primers used might be unable to distinguish members of those groups of fungi associated with cotton seeds.

Among the DNA regions used to compare species within the genus Colletotrichum the Internal Transcribed Spacers (ITS1 and ITS2) of the rDNA, that flank the $5.8 \mathrm{~S}$ gene, are mostly mentioned in literature (SHERRIFF et al., 1994, 1995; BAILEY et al., 1996; SREENIVASAPRASAD et al., 1996; HSIANG and GOODWIN, 2001; DENOYESROTHAN et al., 2003; CANO et al., 2004). By using primers specific to the ITS2 region to characterize Colletotrichum spp. associated with the family Malvaceae, Bailey et al. (1996) found sequence identity of $98.5 \%$ between C. gossypii and C. gossypii var. cephalosporioides. They found the genetic variability between the strains from cotton is relatively low, although only one strain of $C$. gossypii and two strains of $C$. gossypii var. cephalosporioides strains were used. Strains of $C$. gloeosporioides from Aeschynomene virginica, Stylosanthes scabra and Mangifera indica grouped with the strains isolated from cotton while the strains of C. gossypii var. cephalosporioides were also considered part of a subgroup different from that of C. gossypii (BAILEY et al., 1996).

By using rDNA ITS2 sequences, Sherriff et al. (1995) showed that strains of Colletotrichum graminicola isolated from corn were different from the strains of $C$. graminicola obtained from sorghum (Sorghum bicolour L.) and Rottboellia sp., providing further evidence for the classification by Sutton (1980). Accordingly, strains from sorghum and Rottboellia sp. could be considered the $C$. sublineolum species. Besides, analysis of the ITS1 region confirmed the classification (SUTTON, 1980) in which strains from corn and sorghum are considered distinct species (SREENIVASAPRASAD et al., 1996).

Results based on the analysis of DNA sequences from the ITS2 region of strains of Colletotrichum acutatum from strawberries clearly showed the existence of two subgroups: CA-cloned, composed of strains from strawberry, and CAvariable, composed of strains from strawberry and other hosts. This suggests that the strains from strawberry from the CA-cloned subgroup have gone through a process of specialization. In that study, no correlation between genetic groups and pathogenicity was established (Denoyes-Rothan et al., 2003).

Because of the difficulties to associate $C$. gossypii var. cephalosporioides to different degrees of aggressiveness and expression of symptoms, efforts were directed to the genetic characterization of Colletotrichum spp. associated with cotton plants. To date, the results are not sufficient to overcome the problems related to diagnosis. Given the difficulties in distinguishing between the causal agents of cotton ramulosis and anthracnose, and the lack of information about their rDNA ITS1 and ITS2 regions, the objective in the present work was to carry out the phylogenetic characterization of $C$. gossypii strains, considered to be the etiological agent of anthracnose, and of $C$. gossypii var. cephalosporioides strains, the etiological agent of ramulosis, from different geographic origins in Brazil.

\section{MATERIAL AND METHODS}

The work was conducted at the Seed Pathology and the Molecular Plant Virology Laboratories of the Plant Pathology Department of the Federal University of Lavras (UFLA).

Five strains of $C$. gossypii and 17 strains of C. gossypii var. cephalosporioides were analyzed. Strains were obtained from cotton seeds from Campinas, State of São Paulo, and from Lavras, State of Minas Gerais, and part of the strains was supplied by EMBRAPA/CNPA culture collection (Table 1). All strains were characterized by pathogenicity test and stored over activated silica gel at room temperature.

Pathogenicity test. For this test an inoculum suspension, at concentration of $10^{6}$ conidia $\times \mathrm{mL}^{-1}$ was sprayed onto cotton plants of the cultivar NU15, 30 days of age. The plants were kept in a moist chamber at $25^{\circ} \mathrm{C}$ under $12 \mathrm{~h}$ light/ $12 \mathrm{~h}$ dark for 72 hours. The control treatment consisted of plants sprayed with distilled and sterilized water and submitted to the same conditions as those inoculated. The assessments were carried out 30 days after inoculation, following the criteria established by Cia (1977), and adapted by SilvaMann (2002). The experiment was arranged in a randomized complete block design with 23 treatments and four replicates per treatment. The 
data were submitted to variance analysis, and the means were compared by the Tukey test, at a significance level of $5 \%$. The statistical analysis was performed using the Sisvar ${ }^{\mathrm{TM}}$ program (Ferreira, 2000).

Table 1. Geographic origins of isolates of C. gossypii and C. gossypii var. cephalosporioides used in this study.

\begin{tabular}{lcc}
\hline \multicolumn{1}{c}{ Strain } & Cultivar & Geographic origin \\
\hline LPS1005.C. gossypii & $\mathrm{NU}-15$ & Lavras, MG \\
LPS1015.C. gossypii & $\mathrm{NU}-15$ & Lavras, MG \\
LPS1016.C. gossypii & $\mathrm{NU}-15$ & Campinas, SP \\
LPS1020.C. gossypii & $\mathrm{NU}-15$ & Campinas, SP \\
LPS1025.C. gossypii & $\mathrm{NU}-15$ & Campinas, SP \\
AM3F.C. gossypii var. cephalosporioides & $\mathrm{NI}$ & Alto Taquari, MT \\
PF-2a.C. gossypii var. cephalosporioides & $\mathrm{NI}$ & Itiquira, MT \\
AM-1.C. gossypii var. cephalosporioides & Aroeira & Chapadão do Céu, GO \\
PE-1.C. gossypii var. cephalosporioides & ITA-90 & Pedra Preta, MT \\
Cg021.C. gossypii var. cephalosporioides & Ipê & Santa Helena, GO \\
Cg002.C. gossypii var. cephalosporioides & Ipê & Acreúna, GO \\
Cg012.C. gossypii var. cephalosporioides & Ipê & Acreúna, GO \\
PF-3.C. gossypii var. cephalosporioides & Cedro & Pedra Preta, MT \\
PF-1b.C. gossypii var. Cephalosporioides & Cedro & Rondonópolis, MT \\
PF-1a.C. gossypii var. Cephalosporioides & Cedro & Rondonópolis, MT \\
PD-2.C. gossypii var. Cephalosporioides & Cedro & Rondonópolis, MT \\
Cg027.C. gossypii var. Cephalosporioides & Ipê & Santa Helena, GO \\
PF-2b.C. gossypii var. Cephalosporioides & NI & Primavera do Leste, MT \\
PF-1c.C. gossypii var. Cephalosporioides & ITA-90 & Itiquira, MT \\
Cg003.C. gossypii var. Cephalosporioides & Ipê & Acreúna, GO \\
Cg015.C. gossypii var. Cephalosporioides & Ipề & Santa Helena, GO \\
Ca24.C. gossypii var. cephalosporioides & Híbrido Israelense & Novo São Joaquim, MT \\
\hline
\end{tabular}

*Not informed.

DNA extraction. The fungal strains were cultivated in $50 \mathrm{~mL}$ of malt extract broth and incubated for 3 days at $20^{\circ} \mathrm{C}$ on a shaker $(80 \mathrm{rpm})$. Latter, the mycelium was filtered using a vacuum pump and filter paper pads, and $150 \mathrm{mg}$ of the mycelium mass was ground under liquid nitrogen in the presence of polyvinylpyrrolidone (PVP). Genomic DNA was extracted using the method described by Möller et al. (1992), with minor modification. Following extraction, the DNA was treated with $5 \mu \mathrm{L}$ of bovine ribonuclease A $(0.5 \mathrm{mg}$ $\times \mathrm{mL}^{-1}$ ) at $37^{\circ} \mathrm{C}$ for 30 minutes. The DNA was precipitated by the addition of $10 \mu \mathrm{L}$ of $3 \mathrm{M}$ sodium acetate and $275 \mu \mathrm{L}$ of absolute ethanol, and incubation at $-20^{\circ} \mathrm{C}$ for 30 minutes. The supernatant was removed by centrifugation at $14,000 \mathrm{rpm}$, and the DNA pellet was washed with $70 \%$ ethanol, and resuspended in $60 \mu \mathrm{L}$ of TE buffer. The amount and quality of the DNA were assessed by electrophoresis on $0.7 \%$ agarose gels.

Amplification of ITS1, 5.8S, and ITS2 regions. The ITS1, 5.8S, and ITS2 regions of the nuclear ribosomal DNA were amplified by polymerase chain reaction (PCR). Each reaction was performed using $5 \mu \mathrm{L}$ of $10 \mathrm{X}$ PCR buffer $(0.5 \mathrm{M}$ Tris-HCl; $0.7 \mathrm{M} \mathrm{KCl} ; 0.1 \mathrm{M} \mathrm{MgCl}_{2} \mathrm{pH} 8.0$ ), $4 \mu \mathrm{L}$ of $\mathrm{MgCl}_{2}(25 \mathrm{mM}), 5 \mu \mathrm{L}$ of dNTP mix [2mM of each dNTP $(100 \mathrm{mM}) ; 1 \mu \mathrm{L}$ of Tris-HCl pH $8.0(1 \mathrm{M}) ; 1$ $\mu \mathrm{L}$ of DTT $(100 \mathrm{mM}) ; 90 \mu \mathrm{L}$ "ultra pure" water], 1 $\mu \mathrm{L}$ of Taq DNA polymerase $\left(5 \mathrm{U}^{-1}\right), 29.5 \mu \mathrm{L}$ of "ultra pure" water, $2 \mu \mathrm{L}\left(10 \rho \mathrm{mol} \mu \mathrm{L}^{-1}\right)$ of the primers used to amplify the ITS1-5.8S-ITS2 region of the rDNA - ITS4 (5'TCCTCCGCTTATTGATATGC-3') and ITS5 (5'GGAAGTAAAAGTCG TAACAAGG-3') (White et al., 1990). PCR assays were carried out for 35 cycles in a PTC-100 thermocycler (MJ Research, Inc., USA), using the following conditions: 40 seconds at $94^{\circ} \mathrm{C}, 55$ seconds at $50^{\circ} \mathrm{C}, 2$ minutes at $72^{\circ} \mathrm{C}$, followed by a final step of 5 minutes at $72^{\circ} \mathrm{C}$. PCR products were analyzed by electrophoresis on $0.7 \%$ agarose gels stained with ethidium bromide. A 1-kb DNA ladder (Life Technologies) was used as size marker. After capturing the gel image on an Image Master (Pharmacia), the PCR-amplified DNA fragment was excised from the gel, purified using the QIAquick Gel Extraction Kit (Qiagen), and 
sequenced using an ABI 3100 DNA sequencer (Applied Biosystems).

Sequence analysis. Multiple alignments of the sequences of the amplified fragments, comprising the ITS1, 5.8S, and ITS2 regions of the ribosomal DNA, and nucleotide sequences deposited in GenBank were carried out using the ClustalW program (http://www.ebi.ac.uk/clustalw/). The BLAST program (http://www.ncbi.nlm.nih.gov/blast/blast.cgi) was used to search for orthologous Colletotrichum sequences available at the NCBI database (http://www.ncbi.nlm.nih.gov/) (Table 1). Genetic distance was estimated by the UPGMA algorithm. Phylogenetic trees were constructed and visualized using the MEGA3 program (Kumar et al., 2004). Bootstrapping was performed with 1,000 replicates to test the support for each branch of the tree.

\section{RESULTS}

Pathogenicity test. From that test three severity patterns of infection were observed among the Colletotrichum strains (Table 2) based on the disease index proposed by Cia (1977). The severity score 1 group was composed of the strains LPS $1005,1015,1016,1020$, and 1025, which did not induce symptoms on the plants. The severity score 2.5 group was composed of the strains $\mathrm{Cg} 021$, AM3F, PE-1, PF-2a, and AM-1, which induced symptoms of star-shaped spots on the top leaves and reduction in internode length by up to $40 \%$, typical of ramulosis disease. The largest group, with mean severity scores ranging from 2.75 to 3.5 , was represented by the 12 other strains, which induced more severe symptoms including star-shaped spots on the top leaves and reduction in internode length by 40 to $60 \%$, also typical of the disease caused by C. gossypii var. cephalosporioides.

Table 2. Mean severity of ramulosis disease in cotton, cv. NU-15, in trial of inoculation of different Colletotrichum gossypii isolates under controlled conditions.

\begin{tabular}{llcc}
\hline \multicolumn{1}{c}{ Strain } & \multicolumn{1}{c}{ Characterization } & Severity & Symptom \\
\hline LPS1005 & C. gossypii & $1 \mathrm{~b}$ & $\mathrm{PSS}$ \\
LPS1015 & C. gossypii & $1 \mathrm{~b}$ & $\mathrm{PSS}$ \\
LPS1016 & C. gossypii & $1 \mathrm{~b}$ & $\mathrm{PSS}$ \\
LPS1020 & C. gossypii & $1 \mathrm{~b}$ & $\mathrm{PSS}$ \\
LPS1025 & C. gossypii & $1 \mathrm{~b}$ & $\mathrm{PSS}$ \\
AM3F & C. gossypii var. cephalosporioides & $2.25 \mathrm{ab}$ & $\mathrm{PSS} / \mathrm{RI}<40 \%$ \\
PF-2a & C. gossypii var. cephalosporioides & $2.25 \mathrm{ab}$ & $\mathrm{ME} / \mathrm{RI}<40 \%$ \\
AM-1 & C. gossypii var. cephalosporioides & $2.25 \mathrm{ab}$ & $\mathrm{ME} / \mathrm{RI}<40 \%$ \\
PE-1 & C. gossypii var. cephalosporioides & $2.25 \mathrm{ab}$ & $\mathrm{PSS} / \mathrm{ME} / \mathrm{RI}<40 \%$ \\
Cg021 & C. gossypii var. cephalosporioides & $2.25 \mathrm{ab}$ & $\mathrm{PSS} / \mathrm{ME} / \mathrm{RI}<40 \%$ \\
Cg002 & C. gossypii var. cephalosporioides & $2.75 \mathrm{a}$ & $\mathrm{ME} / \mathrm{RI}<40 \%$ \\
Cg012 & C. gossypii var. cephalosporioides & $2.75 \mathrm{a}$ & $\mathrm{ME} / \mathrm{RI}<40 \%$ \\
PF-3 & C. gossypii var. cephalosporioides & $2.75 \mathrm{a}$ & $\mathrm{ME} / \mathrm{RI}<40 \%$ \\
PF-1b & C. gossypii var. cephalosporioides & $2.75 \mathrm{a}$ & $\mathrm{ME} / \mathrm{RI}<40 \%$ \\
PF-1a & C. gossypii var. cephalosporioides & $2.75 \mathrm{a}$ & $\mathrm{PSS} / \mathrm{RI}<40 \% / \mathrm{SB}-\mathrm{RD} 40-60 \%$ \\
PD-2 & C. gossypii var. cephalosporioides & $2.75 \mathrm{a}$ & $\mathrm{ME} / \mathrm{RI}<40 \% / \mathrm{SB}-\mathrm{RD} 40-60 \%$ \\
Cg027 & C. gossypii var. cephalosporioides & $3.25 \mathrm{a}$ & $\mathrm{RI}<40 \% / \mathrm{SB}-\mathrm{RD} 40-60 \%$ \\
PF-2b & C. gossypii var. cephalosporioides & $3.5 \mathrm{a}$ & $\mathrm{RI}<40 \% / \mathrm{SB}-\mathrm{RD} 40-60 \%$ \\
PF-1c & C. gossypii var. cephalosporioides & $3 \mathrm{a}$ & $\mathrm{ME} / \mathrm{RI}<40 \% / \mathrm{SB}-\mathrm{RD} 40-60 \%$ \\
Cg003 & C. gossypii var. cephalosporioides & $3 \mathrm{a}$ & $\mathrm{RI}<40 \%$ \\
Cg015 & C. gossypii var. cephalosporioides & $3 \mathrm{a}$ & $\mathrm{RI}<40 \%$ \\
Ca24 & C. gossypii var. cephalosporioides & $3 \mathrm{a}$ & $\mathrm{ME} / \mathrm{RI}<40 \%$ \\
Test & & $1 \mathrm{~b}$ & $\mathrm{PSS}$ \\
\hline
\end{tabular}

Values followed by a common letter are not statistically different $(P \leq 1 \%)$ as determined by the Tukey test. PSS = plant without symptom, ME $=$ star-shaped spot, RI $<40 \%=$ reduction in internode length by up to $40 \%$, SB-RD 40 to $60 \%=$ witch's-broom and reduction in internode length by 40 to $60 \%$.

Nucleotide sequence analyses. A fragment of approximately 500-bp long comprising the complete sequences of the ITS1, 5.8S gene, and ITS2 regions of the ribosomal DNA was obtained from all Colletotrichum strains from cotton considered in this study by PCR assays using the primers ITS4 and ITS5. As for the individual rDNA regions sequence sizes, they were 167-168-bp, 159$\mathrm{bp}$, and 177-bp long for the ITS1, 5.8S gene, and ITS2 regions, respectively. 
Multiple sequence alignment of the rDNA ITS1 region of the 22 analyzed Colletotrichum strains from cotton revealed sequence identities ranging from 96 to $100 \%$. Although the strains $\mathrm{Cg} 027$ and AM-1 were identified as $C$. gossypii var. cephalosporioides by the pathogenicity test in this work, they presented the lowest sequence identity based on the ITS1 region (Figure 1). In contrast, the highest sequence identity was observed between the ITS1 regions of the $C$. gossypii strains LPS1015 and LPS1020, as well as between LPS1015 and LPS1025. The other strains showed sequence identities of $98-99 \%$. The identity between the $C$. gossypii and C. gossypii var. cephalosporioides ITS1 sequences varied from 97 to $100 \%$. The strains
LPS1015 and LPS1025 showed 100\% ITS1 sequence identity to those of 10 out of the $17 C$. gossypii var. cephalosporioides strains. Among the fungal strains sequences, only the strain LPS1016 showed sequence identities of $97-99 \%$ to the strains associated with ramulosis, while the ITS1 regions of the strains LPS1015 and LPS1020 exhibited 100\% identity to the regions of five of the 17 C. gossypii var. cephalosporioides strains. Among the $C$. gossypii var. cephalosporioides strains, PF-1b, PE-1 and PF-3 showed $100 \%$ ITS1 sequence identity to 10 strains, whereas the AM-1 strain has shown to be most divergent, sharing less than 100\% ITS1 sequence identity with the other strains.

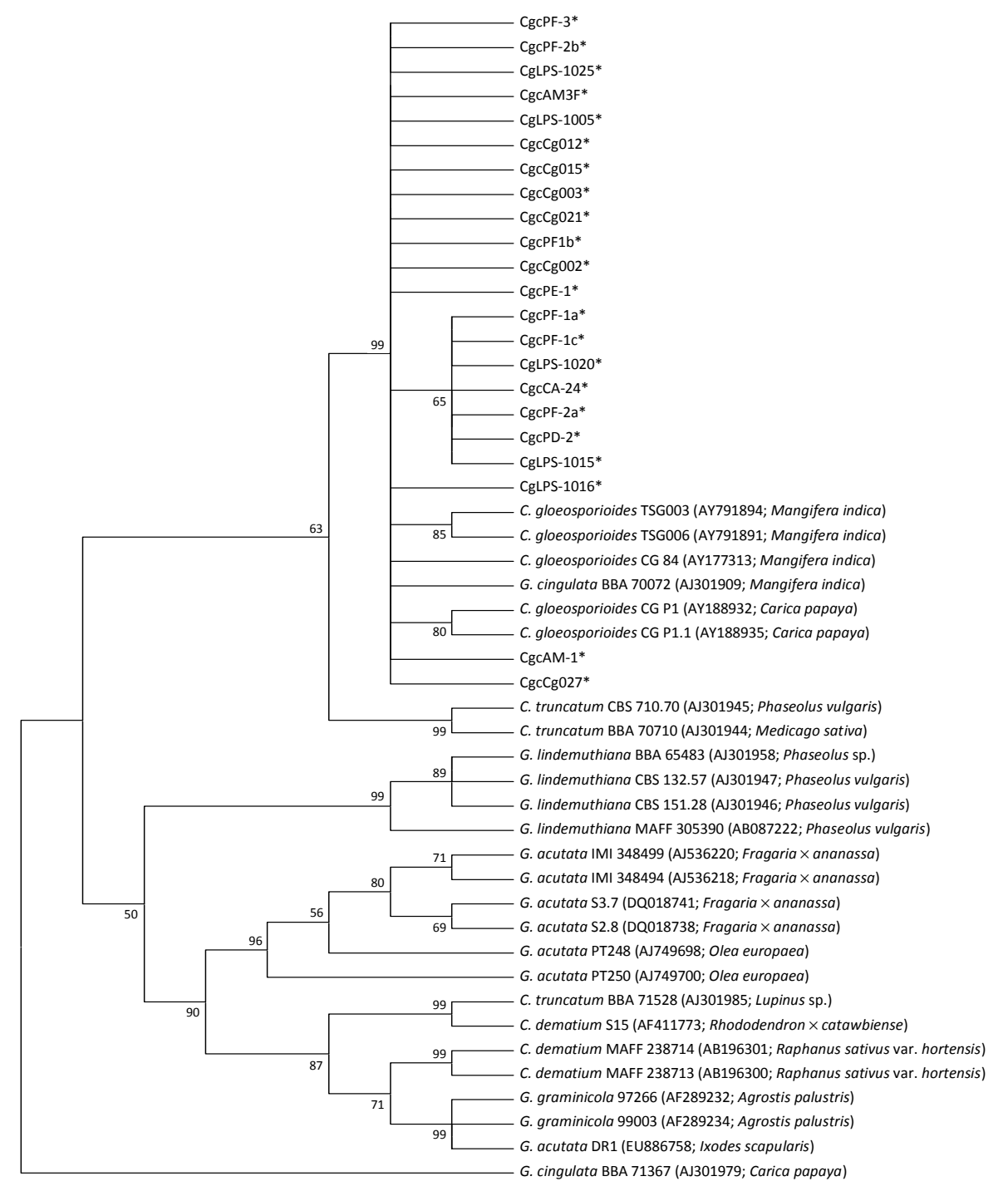

Figure 1. ITS1 rDNA sequence-based phylogenetic tree of Colletotrichum strains and orthologous species deposited in GenBank. Bootstrap values (UPGMA algorithm) were calculated using MEGA program version 3.1. Values greater than 50\% (from 1,000 bootstrap replicates) are shown at nodes. GenBank accession numbers and host plants are indicated between brackets.

*Sequences from strains belonging to the cotton plant complex. 
Smaller variation was found in the rDNA ITS2 region between the 22 strains, as compared to the ITS1 region (Figure 2). The majority of strains of each fungus showed $100 \%$ sequence identity, except the strains: $\mathrm{Cg} 021, \mathrm{Cg} 027, \mathrm{PF}-1 \mathrm{~b}, \mathrm{PF}-3$ and AM-1.

Sequence alignment analyses of the rDNA ITS2 region of all strains including those from GenBank revealed $100 \%$ nucleotide sequence identity between the strains considered in this study and the strains BBA 70072 and CG 84 of $G$. cingulata from mango. Identity of $95 \%$ was found in sequence alignments with the other mango strains (TSG003 and TSG006), and the papaya strains CG P1 and CG P1.1.

Similarly, Bailey et al. (1996) found 96$98 \%$ nucleotide sequences identity between $C$. gossypii and C. gossypii var. cephalosporioides strains obtained in Brazil and Argentina, including the strains considered in this study, which grouped together with the strains from mango and papaya.

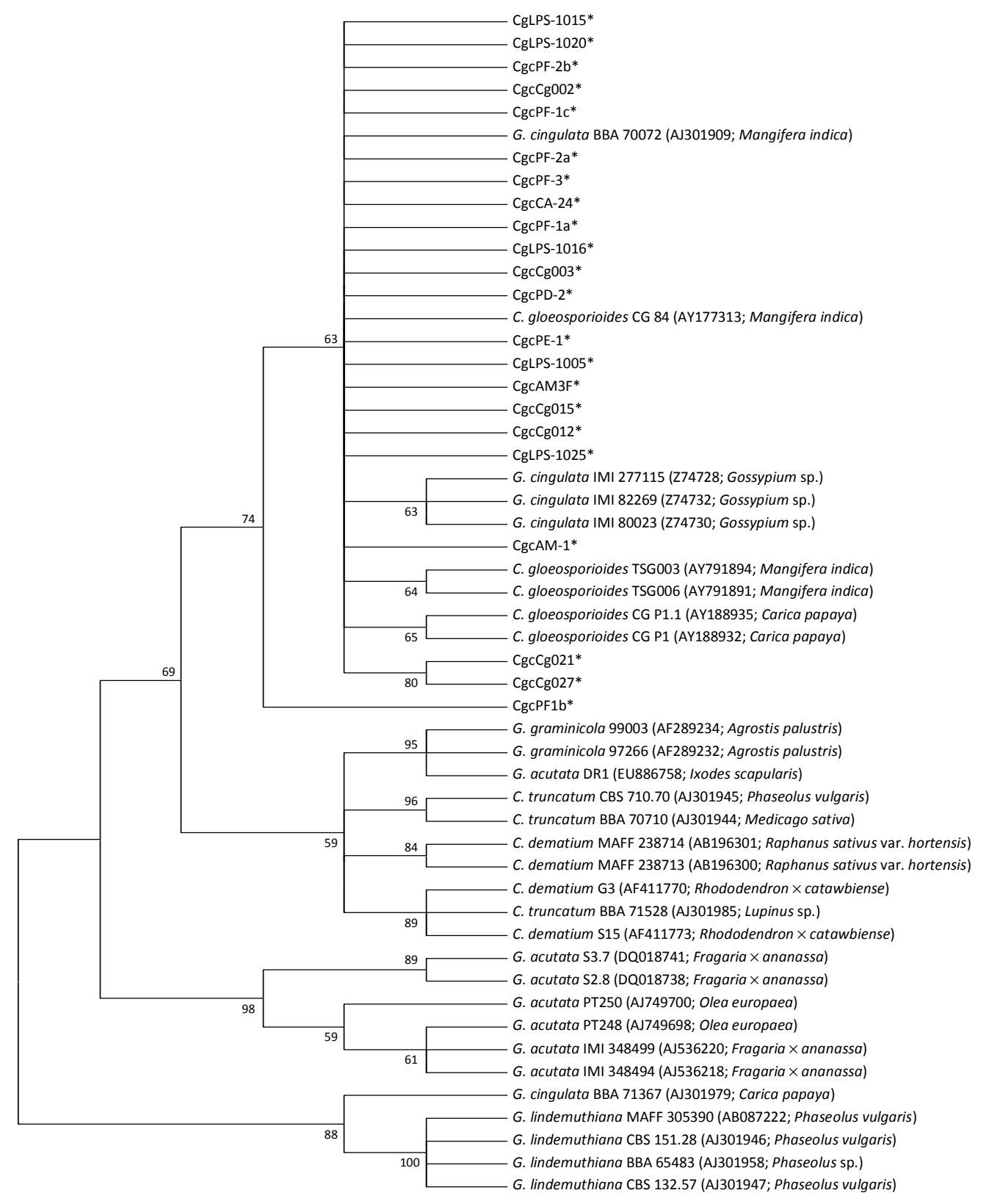

Figure 2. ITS2 rDNA sequence-based phylogenetic tree of Colletotrichum strains and orthologous species deposited in GenBank. Bootstrap values (UPGMA algorithm) were calculated using MEGA program version 3.1. Values greater than 50\% (from 1,000 bootstrap replicates) are shown at nodes. GenBank accession numbers and host plants are indicated between brackets.

*Sequences from strains belonging to the cotton plant complex. 


\section{DISCUSSION}

The variability in aggressiveness among Colletotrichum strains has already been reported by other authors on inoculated plants of cotton cultivars, showing that the interaction between pathogen and host may be quite complex (DUDIENAS, 1990; IAMAMOTO, 2002; SILVAMANN, 2002). In this work another evidence of that interaction was observed on some plants in that the severity score 1 group exhibited slight necrosis of leaf veins, a symptom not considered in the rating scale proposed by Cia (1997). Although this symptom has been ascribed to ramulosis, it is typical of anthracnose in other crops.

Nucleotide alignment between sequences of the strains considered in this study and the majority available at the NCBI database revealed identities ranging from 80 to $88 \%$, showing a clear distinction of species. The highest sequence identities were shown to the strains that colonize papaya, CG P1 (94-96\%) and CG P1.1 (95-97\%), and to the mango strains TSG003, TSG006 and CG 84 (95-97\%), and BBA 70072 (95-96\%), suggesting a close relationship between them. The lowest sequence identities were found in relation to the strain BBA 71367 from papaya (72-76\%). This strain also exhibited low sequence identities (varying from 75 to $85 \%$ ) to the other strains in the NCBI database, including those from papaya - CG P1 (75\%) and CG P1.1 (77\%).

By the phylogenetic and pathogenicity analyses (Table 2, Figures. 1 and 2), C. gossypii and C. gossypii var. cephalosporioides strains did not differ significantly based on their ITS1 and ITS2 nucleotide sequences, which is not in agreement with the taxonomical classification as distinct fungi. These findings lead the direction of this investigation to shift to other approaches considering for example analysis of other DNA regions and proteomics analysis in addition to the use of other molecular techniques

According to the ITS1 sequence-based phylogenetic tree (Figure 1), C. gossypii and $C$. gossypii var. cephalosporioides belong to the same cluster, indicating a close relationship between them. The strains from mango and papaya, with higher sequence identity, also grouped together. The other strains represent distinct groups: $C$. truncatum strain CBS 710.70, from lupin, and BBA 70710 strain, from alfalfa, are the most closely related strains. Such specialization within and between host groups has been reported in literature (SHERIFF et al., 1995; HSIANG; GOODWIN, 2001; DENOYES-ROTHAN et al., 2003).

In relation to the alignment of the $5.8 \mathrm{~S}$ gene sequences of the 22 fungal strains, it was revealed high nucleotide identity (98-100\%) to each other. Similar results were obtained when comparing those sequences to ones available in GenBank (97-100\% sequence identity). That provides further evidence for the low variability of this region which is considered to be highly conserved among fungal species (MILLER et al., 1999; SILVA-HANLIN et al., 1999; FUNGARO, 2000).

According to the ITS2 sequence-based phylogenetic tree (Fig. 2), the strains associated with anthracnose and ramulosis of cotton clustered together in a group including strains associated with mango and papaya, except the strain PF-1b of $C$. gossypii var. cephalosporioides which differed from the group comprised of the above-mentioned strains. In general the strains from the GenBank tended to group according to each fungal species in this work, with the exception of the strain BBA 71367 of $G$. cingulata from papaya, which clustered with $C$. lindemuthianum strains.

\section{ACKNOWLEDGMENTS}

This work was supported by Conselho Nacional de Desenvolvimento Científico e Tecnológico (CNPq), Coordenação de Aperfeiçoamento de Pessoal de Nível Superior (CAPES) from Federal Government of Brazil and Fundação de Amparo à Pesquisa do estado de Minas Gerais (FAPEMIG). Thanks to Dr. Nelson Dias Suassuna (EMBRAPA/CNPA) for his support on the experiment.

RESUMO: O uso de sequências de fragmentos de DNA tem sido importante ferramenta para distinguir e identificar populações de organismos em diferentes níveis de variação. Por meio de marcadores moleculares alguns organismos com variações taxonômicas complexas têm sido detectados com sucesso em tecidos vegetais. O DNA ribossomal tem sido utilizado para avaliar variabilidade genética, filogenia de micro-organismo e para desenvolver oligonucleotídeos específicos visando à detecção de fitopatógenos. Nesse estudo o objetivo foi comparar isolados do complexo Colletotrichum, incluindo C. gosssypii var. cephalosporioides e C. gossypii, coletados em diferentes regiões do Brasil, todos associados às sementes de algodão, pela análise de sequências de nucleotídeos de regiões de rDNA. ITS1, ITS2 e o gene 5.8S que foram amplificados por PCR e suas sequências comparadas entre si com outras sequências 
depositadas no GenBank. O rDNA de isolados associados com Gossypium spp. mostraram identidades de sequências na faixa de 96 to $100 \%$ na região ITS1, 98 to $100 \%$ na região de $5.8 \mathrm{~S}$, e 97 a $100 \%$ na região ITS2. As sequências foram submetidas a análise UPGMA, e de acordo com as árvores filogenéticas , C. gossypii var. cephalosporioides e C. gossypii fizeram parte de um mesmo cluster junto com isolados de Glomerella cingulata de manga e mamão, e assim nenhuma distinção pode ser feita entre os isolados destes organismos.

PALAVRAS-CHAVE: Colletotrichum gossypii. Colletotrichum gossypii var. cephalosporioides. rDNA, phylogeny. Gossypium spp.

\section{REFERENCES}

ARAÚJO, D. V.; POZZA, E. A.; MACHADO, J. C.; ZAMBENEDETTI, E. B.; CARVALHO, E. M.; CELANO, F. A. O. Relação entre níveis de inóculo de Colletotrichum gossypii var. cephalosporioides nas sementes e o progresso da ramulose do algodoeiro. Fitopatologia Brasileira, Brasília, v. 31, p. 147-151, 2006. http://dx.doi.org/10.1590/S0100-41582006000200004

ARX, J. A. Die arten der gattung Colletotrichum Cda. Phytopatholojische Zeitschrift, Berlin, v. 29, p. 413468, 1957.

BAILEY, J. A.; NASH, C.; MORGAN, L. W.; O'Connell, R. J.; TEBEEST, D. O. Molecular taxonomy of Colletotrichum species causing anthracnose on the Malvaceae. Phytopathology, St. Paul, v. 86, p. 1076-1083, 1996.

CANO, J.; GUARRO, J.; GENÉ, J. Molecular and morphological identification of Colletotrichum species of clinical interest. Journal of Clinical Microbiology, Washington, v. 42, p. 2450-2454, 2004.

http://dx.doi.org/10.1590/S0100-41582006000200004

CARVALHO, D.; VIEIRA, M. G. G. C.; MACHADO, J. C. Uso de isoenzimas para diferenciação de Colletotrichum gossypii e C. gossypii var. cephalosporioides isolados de sementes de algodão. Revista Brasileira de Sementes, Londrina, v. 19, p. 315-319, 1997.

CHITARRA, G. S. Variabilidade cultural de Colletotrichum associado a sementes de algodão e sua diversidade genética através de marcadores RAPD sob condições padrões do teste de sanidade. 1996. 56 p. Dissertation (M.Sc in Phytopathology). Federal University of Lavras (UFLA), Brazil, 1996.

CIA, E. Ocorrência e conhecimento das doenças do algodoeiro anual Gossypium hirsutum L. no Brasil. Summa Phytopathologica, Botucatu, v. 3, p. 167-193, 1977.

COSTA, A. S.; FRAGA JUNIOR, C. G. Superbrotamento ou ramulose do algodoeiro. Revista de Agricultura, Piracicaba, v. 7, p. 249-259, 1937

DENOYES-ROTHAN, B.; GUÉRIN, G.; CHRISTOPHE, D.; SMITH, B.; MINZ, D.; MAYMON, M.; FREEMAN, S. Genetic diversity and pathogenic variability among isolates of Colletotrichum species from strawberry. Phytopathology, St. Paul, v. 93, p. 219-228, 2003.

DUDDIENAS, C. Caracterização morfológica, auxonográfica e patogênica de Colletotrichum gossypii e $C$. gossypii var. cephalosporioides Costa \& Fraga Jr. 1990. 67 p. (M.Sc. Dissertation in Phytopathology). "Luiz de Queiroz" College of Agriculture/University of São Paulo (ESALQ/USP), Brazil, 1990.

FERREIRA, D. F. Análises estatísticas por meio do Sisvar para Windows versão 4.0. In: XLV REUNIÃO ANUAL DA REGIÃO BRASILEIRA DA SOCIEDADE INTERNACIONAL DE BIOMETRIA, 45., 2000. São Carlos. Anais... Brazil 2000. p. 255-258. 
FUNGARO, M. H. P. PCR na micologia - diagnóstico e análise de variabilidade. Biotecnologia, Ciência e Desenvolvimento, Brasília, v. 17, p. 12-16, 2000.

HSIANG, T.; GOODWIN, P. H. Ribosomal DNA sequence comparisons of Colletotrichum graminicola from turfgrasses and other hosts. European Journal of Plant Pathology, v. 107, p. 593-599, 2001.

http://dx.doi.org/10.1023/A:1017974630963

IAMАМОТО, M. M. Ramulose do algodoeiro (Colletotrichum gossypii var. cephalosporioides): reação de genótipos e variabilidade do patógeno. 2002. 57 p. (Ph.D. Thesis in Vegetable Production). São Paulo State University, Brazil, 2002.

KUMAR, S.; TAMURA, K.; NEI, M. MEGA3: an integrated software for molecular evolutionary genetics analysis and sequence alignment. Briefings in bioinformatics, Oxford, v. 5, p. 150-163, 2004.

LIMA, E. F.; CARVALHO, J. M. F. C.; CARVALHO, L .P.; COSTA, J. N. Transporte e transmissão de Colletotrichum gossypii South. var. cephalosporioides A. S. Costa através da semente do algodoeiro.

Fitopatologia Brasileira, Brasília, v. 10, p. 99-109, 1985.

MEHTA, Y. R.; AVANZI, C.; CALVO, E. Molecular characterization of Colletotrichum gossypii isolates from cotton. In: III CONGRESSO BRASILEIRO DE ALGODÃO, 3., 2001, Campo Grande. Anais... Brazil 2001. p. $32-35$.

MILLER, R. N. G.; QUEZADO-SOARES, A. M.; LOPES, C. Molecular comparison of Fusarium populations causing eumartii wilt and dry rot of potato in Brazil. Fitopatologia Brasileira, Brasília, v. 24, p. 149-155, 1999.

MOLLER, E. M.; BAHNWEG, G.; SANDERMANN, H.; GEIGER, H. H. A simple and efficient protocol for isolation of high molecular weight DNA from filamentous fungi, fruit bodies, and infected plant tissues.

Nucleic Acids Research, Oxford, v. 20, p. 6115-6116, 1992. http://dx.doi.org/10.1093/nar/20.22.6115

OTTONELO, A. M. P. Caracterização cultural, patogênica e serológica de Colletotrichum da antracnose e da ramulose do algodoeiro. 1992. 68 p. (M.Sc. Dissertation in Phytopathology). "Luiz de Queiroz" College of Agriculture/University of São Paulo (ESALQ/USP), Brazil, 1992.

SHERRIFF, C.; WHELAN, M. J.; ARNOLD, G. M.; LAFAY, J. M.; BRYGOO, J.; BAILEY, J.A. Ribosomal DNA sequence analysis reveals new species groupings in the genus Colletotrichum. Experimental Mycology, v. 18, p. 121-138, 1994. http://dx.doi.org/10.1006/emyc.1994.1014

SHERRIFF, C.; WHELAN, M. J.; ARNOLD, G. M.; BAILEY, J. A. rDNA sequence analysis confirms the distinction between Colletotrichum graminicola and Colletotrichum sublineolum. Mycological Research, Ardwick, v. 99, p. 475-478, 1995.

SILVA-HANLIN, D. M. W.; MENEZES, M.; HANLIN, R. T.; RAMALHO-NETO, C. E. Ribosomal DNA sequencing data reveals low genetic variability among Fusarium oxysporum $\mathrm{f}$. sp. cubense isolates.

Fitopatologia Brasileira, Brasília, v. 24, p. 534-539, 1999.

SILVA-MANN, R. Diversidade do complexo de Colletotrichum e de cultivares de algodoeiro por meio de marcadores moleculares. 2002. 146 p. (Ph.D. Thesis in Seed Technology. Federal University of Lavras (UFLA), Brazil, 2002.

SILVA-MANN, R.; SALGADO, K. C. C.; VIEIRA, M. G. G. C.; MACHADO, J. C. Variabilidade genética de isolados do complexo Colletotrichum associados a semente de algodoeiro por meio de técnicas moleculares e inoculação em plantas. Fitopatologia Brasileira, Brasília, v. 27, p. 27-32, 2002.

http://dx.doi.org/10.1590/S0100-41582002000100004 
SILVA-MANN, R.; VIEIRA, M. G. G. C.; MACHADO, J. C.; BERNARDINO FILHO, J. R.; SALGADO, K. C. C.; STEVENS, M. R. AFLP markers differentiate isolates of Colletotrichum gossypii from C. gossypii var. cephalosporioides. Fitopatologia Brasileira, Brasília, v. 30: p. 169-172, 2005.

SREENIVASAPRASAD, S.; MILLS, P. R.; MEEHAN, B. M.; BROWN, A. E. Phylogeny and systematics of 18 Colletotrichum species based on ribosomal DNA spacer sequences. Genome, v. 39, p. 499-512, 1996. http://dx.doi.org/10.1139/g96-064

SUTTON, B. C. The coelomycetes. Kew, Surrey, England: Commonwealth Mycological Institute, 1980. 696 p.

SUTTON, B. C. The genus Glomerella and its anamorph Colletotrichum. In: Bailey, J.A., Jeger, M.J. (Eds.)

Colletotrichum: Biology, Pathology and Control. Wallingford: CAB International, 1992. p.1-26.

TANAKA, M. A. S. Patogenicidade e transmissão por sementes do agente causal da ramulose do algodoeiro. 1990. 111 p. (Ph.D. Thesis in Phytopathology). "Luiz de Queiroz" College of Agriculture/University of São Paulo (ESALQ/USP), Brazil, 1990.

TANAKA, M. A. S. Problemas da detecção do agente causal da ramulose em sementes de algodão. In: Menten, J. O. M. (ed.) Patógenos em Sementes: Detecção, Danos e Controle Químico. São Paulo: Ciba Agro. 1995. p. 93-108.

VIÉGAS, A. P. Alguns fungos do Brasil. XII. Fungi Imperfecti (Melanconiales). Bragantia, Campinas, v. 6, p. 1-37, 1946. http://dx.doi.org/10.1590/S0006-87051946001100002

VIEIRA, M. G. G. C. Utilização de marcadores moleculares no monitoramento da qualidade sanitária e nível de deterioração de sementes de algodoeiro (Colletotrichum hirsutum L.). 1996. 114 p. (Ph.D. Thesis in Seed Technology). Federal University of Lavras (UFLA), Brazil, 1996.

VIEIRA, M. G. G. C. Técnicas Moleculares em Sementes. Lavras, Brazil: UFLA/FAEPE. 2002. 86 p.

VIEIRA, M. G. G. C.; MACHADO, J. C. Applicability of techniques for detection of seed-borne fungi under certification. In: Machado, J.C., Langerak, C.J., Jaccoud-Filho, D.S. (eds.). Seed-Borne Fungi: A Contribution to Routine Seed Health Analysis. Bassersdorf, Switzerland: ISTA. 2002. P. 82 - 91.

WHITE, T. J.; BRUNS, T.; LEE, S.; TAYLOR, J. W. Amplification and direct sequencing of fungal ribosomal RNA genes for phylogenetics. In: INNIS, M.A.; GELFAND, D.H.; SNINSKY, J.J.; WHITE, T.J. (Eds.). PCR protocols: a guide to methods and applications. San Diego: Academic, 1990. P. 315 -322.

http://dx.doi.org/10.1016/B978-0-12-372180-8.50042-1 